\title{
Revealing Medan's Chinese Ethnic Identity in Advertising Grief at Harian Analisa Newspaper
}

\author{
Agung Suharyanto ${ }^{1}$, Taufik Wal Hidayat ${ }^{1}$ \\ Communication Studies Program, Faculty of Social and Political Sciences, Medan Area University, Indonesia \\ agungsuharyanto@staff.uma.ac.id
}

\begin{abstract}
The purpose of this paper is to reveal the mass media and commodity relations of death to the Medan Chinese in the advertisement of mourning in the Harian Analisa newspaper. The method used in this study was descriptive to reveal the mass media and commodity relations of death to Chinese ethnic in Medan in the advertisement of mourning in the daily newspaper The analisa was clear. Data obtained from the results of direct interviews with speakers are qualitative data used to answer the research objectives. The results obtained were Mass Media and the Relationship of Death Commodities to Chinese Ethnicity in Condolence Advertisements in Harian Analisa Newspapers in Medan are two things that are closely related to respect for ancestors as well as the economy. These two activities were embodied by the Harian Analisa Newspaper managed by Chinese people. The Grief Advertisements in Harian Analisa , became one of the Chinese Ethnic identity markers in Medan, which distinguishes it from other ethnicities in Medan City. There are two types of death advertisements, namely Grief News and Grief. Anatomy of Grief Ads: Headline; Sub Headline; Name; Bodycopy; Family name; Photos and Frames. Chinese Ethnic Identity, seen from the presence of Condolence Advertisements in Harian Analisa Newspaper as one of the teachings that the brand is still doing to Repay Budi to People Who Ever Helped; Maintain Closer Kinship in the family; Social Bonding and Togetherness, Cultural Defense and Respect for Ancestors.
\end{abstract}

Keywords: ethnicity; chinese; condolence advertisements; medan Harian Analisa.

\section{Introduction}

Chinese ethnicity, is one of the many ethnicities whose existence actually adds diversity in the city of Medan, Discussing the Chinese Ethnic community in Medan cannot ignore the history of the 3 waves of their spread throughout the world. The first wave occurred before 1882, mostly illiterate, namely poor farmers and wide-hooded coolies and long braids. The second wave between 1882-1943 generally traded or went to school and the third wave was mostly women and children who followed their husbands or parents who wandered (Wibisono, 2006:13). The three periods were then classified into two (2) major parts, namely China Descendants and China original.

As an immigrant community in the city of Medan with a long history of travel, the ethnic Chinese focus more on their activities in the field of trade. Although when viewed, from the process of his arrival which occurred three periods, but the activities of the Chinese ethnic community, basically the same, namely as traders. This prominent field of life, in the end was able to become a group that controls trade in Medan.

Activities that personally and even privacy, give color to the city of Medan, as a city that does not have a dominant culture. Where the cultural elements of each ethnic group (ethnic group) have diverse and significant characteristics. Ethnic diversity or diversity refers to the existence of many ethnicities where one is not inferior to the other, thus encouraging the strengthening of the identity of each ethnic in the city of Medan. 
In identity, there is no ethnic group that can maintain an identity that can be believed without signs, symbols, which underlies the values that show a clear identity, however the signs and symbols are the result of interaction with the group - other groups and comprehensive signs of ethnic values and development as such to bring out a positive image to transcend boundaries.

Barth (1967: 12-13) asserts that ethnic groups can be known as cultural units and as order. As a cultural unit, ethnic groups can be observed from: i) continuity of cultural units and ii) the existence of factors that influence the formation of the cultural unit. And vice versa, as an order, ethnic groups show the existence of group uniqueness that is ascriptive and can be estimated in terms of background, origin. The group will be formed if someone uses his ethnic identity in categorizing himself with other people in the purpose of interaction. However, interaction and social contact will not necessarily eliminate the real identity of someone who is in contact, because in conducting social interactions and contacts, it takes a common sign that can be accepted by both parties with the formation of a particular social system. Such interactions will not result in mixing with cultural change. This difference will only survive even though ethnic relations occur. The similarity of the sign is needed because of mutual benefit (mutualism) between the two parties. (Barth, 1967: 10)

Furthermore, Barth (1967: 14) emphasizes that cultural characteristics that indicate an ethnic group can change, as well as the cultural nature of members can change shape, even social group arrangements can change; but the fact that the dichotomy continues from group members to other people makes it possible to determine the nature of the settlement and from where the investigation is carried out. Therefore, ethnic groups can be identified as long as they show differences with other groups. This difference certainly does not only cover objective and subjective aspects, but it will be better if it integrates with the aspects of sociocultural dynamics which will certainly affect both elements.

\section{Research Methods}

This research is a qualitative descriptive research that is a method used to investigate and solve problems that are not limited to data collection and compilation. This descriptive method is used to describe the facts relating to the problem under study as it is. This can be seen from the characteristics shown that the data used in research is in the form of words or sentences and even numbers but examines data in the form of a description or statement.

In addition, ethnographic research is also used because this trend continues to this day, namely the existence of Condolence Advertisements in the Medan Harian Analisa Newspaper which is still used as a medium of interaction among ethnic Chinese in Medan.

The data collection instrument is divided into two, namely for primary data using gathering condolence advertisements in the Medan Harian Analisa newspaper in June 2018 and direct interviews with several Chinese figures and ethnic communities in Medan. This interview is carried out by interview, the method of collecting data through direct interviews conducted in depth to the data source. As for secondary data from a review of various literature relevant to research.

Data collection in this study was carried out using referral methods, note the literature study of interviews and documentation. Data collection was carried out through: Literature study through two activities, namely collecting condolence advertisements in the Medan Harian Analisa newspaper. In addition, it also examines various literatures that are relevant 
to the research and compares several writings or other research results that have already been done with research subjects almost the same.

The interview technique is a conversation with a specific purpose. The conversation was carried out by two parties, namely the interviewer (interviewer) who asked the question and interviewed (interviewee) who gave the answer to the question (Moleong, 2006: 186). This was done with a number of informants consisting of ethnic Chinese communities in Medan and several figures and communities who knew/understood the problems to be studied. The interview technique is used to find out information from the resource person. The researcher interviewed directly with someone who was of ethnic Chinese descent and asked about the sad news or the structure of the discourse in the sad news and the researcher noted it. The researcher also interviewed one of the parties from the newspaper, because it aimed to find out in detail about the sad news that was in the newspaper. Documentation is used as additional information for the author and displays the documentation of the event.

All data that has been collected from the results of library studies, interviews and documentation, are sorted on the basis of their reliability and validity. Next is data reduction, where at this stage the researcher focuses on the collected data. The selected data will be simplified in the sense of classifying the data and abstraction of the rough data into a brief description or summary. This is to clarify and unify data so as to facilitate data analysis.

Analyzing data is describing or sorting out the words so that the status of a data is clearly visible. Besides this research the data analysis technique used is descriptive technique. Data is described so that status and meaning clearly appear concise, solid, effective, interesting and attractive. At the data analysis stage the researcher seeks to examine directly the problems contained in the data. The handling appears to be an act of observing which is immediately followed by dissecting or describing the problem in a certain way (Mastoyo, 2007: 47).

After the data is collected both obtained from the literature and obtained in the field then data classification is carried out, then the data that is related and relevant to the problem under study is selected. Data that has been selected and encrypted, processed and analyzed by descriptive analysis method, namely data is simplified into a form that is easier to read and interpret, so that it can be seen the realization of the problem under study whether in accordance with the existing implementation.

At this stage triangulation techniques are carried out. Trianggulasi is a technique based on the phenomenological mindset that is multiperspective. Data triangulation was carried out by the way researchers read, listened to, and sorted out sad news in the Medan Harian Analisa newspaper.

\subsection{Death Must Be Reported as a Respect.}

\section{Results and Discussion}

Ancestors of Chinese before knowing religion, in fact they have known respect for ancestors. From that respect that became the basis of trust and became the basis of traditional Chinese beliefs until now. Until now Chinese people still consider this death to be a taboo thing to talk about, especially when someone is planning to marry or give birth to a child. For Chinese people, someone who has died automatically changes his status to a god, even his age may be added to three years (one year for Earth, one year for air and one year for the sea), therefore that person must be worshiped especially by those who are more young, including grandchildren. 
Worship is carried out in the tomb, besides that it can also be done at home by calling the spirit of the spirit in front of the altar (Hio Lo). Usually this Hio Lo is installed in the home of the eldest son, except with the family's consent it may be placed in another child's home. Nowadays there are special facilities for laying ancestral ashes, and there are volunteers who are willing to take care of them. To find out whether the spirit that was called was present or not, Puak Poi was held by throwing two coins. If the fall differs three times in a row, that means the spirit of the spirit called is present.

\subsection{Mass Media and Grief Ads}

For humans language is a very important communication tool, with that language, people can convey various inner news, thoughts, and hopes to fellow humans. With that language also people can receive and convey all knowledge, hopes, and messages. Because of the position of such language, language is encountered in all areas of human life, including in the field of advertising. Communication activities not only involve a participant, but also involve other participants. In order for participants to understand the intentions of each other's speech, the research must have good cooperation. As one of the areas of human life, advertising and advertising have a very important role if viewed in terms of economics, sociology, psychology, and communication. In terms of economy and business, advertising is the most effective sales tool or the most important promotional tool, which moves with mass media channels to a wide audience to offer goods or services. Advertising is the most effective way to attract a number of consumers.

Advertising offers a value system in social life, in terms of psychology, advertising affects a person's motivation in making decisions and acting. Whereas, in terms of advertising communication concerning the effectiveness of advertising media as an advertising communication tool concerning the effectiveness of advertising media as a communication tool. Advertising is one form of communication consisting of information and ideas about a product that is aimed at the audience simultaneously in order to get a good reception. Advertising tries to provide information, persuade and convince. In other words, advertising is the most effective means of communication to disseminate information, product products, services and ideas from the advertiser, to the audience. Ads can contain several kinds, one of which contains sad news, namely advertisements containing grief news that aims to provide information to other people who do not know when they died or provide information to relatives who are remotely via newspapers. mourning advertisements are closely related to efforts to disseminate the news of the death of a Chinese ethnic to a family and relatives of fellow Chinese.

In addition to the message of death, sorrow advertisements convey another message. for families of Chinese people who were involved in business and trade during their lifetime, sorrow advertising was expected to inform the business relation of the deceased. In terms of the economic aspects of the media, grief advertising is relatively stable in contributing to income. Both the media in the past and now rely on family news advertisements, both grief and joy advertisements. As soon as a family member dies, a family member, usually a deceased child, immediately invites a discussion to determine the time for burial. After agreeing and obtaining a good day and date, they immediately contact the advertising agency or the death service foundation to prepare the sorrow advertisements. Grief advertising is a form of symbolic expression of culture which is a transformation of human culture that is very ancient. When someone dies. Then the notification of death events is disseminated in 
various ways and through various media. The process of disseminating the death news becomes an extraordinary thing when the deceased person has a position, or a special position in the community. For example, a king who proclaims death by gathering people massively and proclaiming it by word of mouth,

Nowadays it is more practical to do with evidence of grief in the mass media. Especially in Harian Analisa, it is positioned as an important part of media content. in addition to being a source of income, the space used is also not small. Quite often it even exceeds the space allocated for news, articles or other commercial advertisements. News of death in Harian Analisa takes equal space to compete with other advertisements that are not as high as the value of their commodities.

Ads are news orders to encourage, persuade the general public to be interested in the goods and services offered and notices to the public about the goods and services sold, installed in mass media such as newspapers and magazines, or in public places (Indonesian Dictionary). While according to Frank Jefkins (1997) advertising is a message directed to persuade people to buy. The standard definition of advertising usually contains six elements: Advertising is a form of communication that is paid, In addition to the message that must be delivered must be paid, in the advertisement also occurs the process of identifying the sponsor. Advertisements not only display messages about the greatness of the products offered, but also convey a message so that consumers are aware of the companies that produce the products offered.

In simple terms, advertising is defined as "A message that offers a product that is addressed to the public through the media". Basically, the only purpose of advertising is to sell a product, service or idea or the real purpose is effective communication, which is where the final effect of advertising is to change the attitude or behavior of the recipient of the message.

Grief ads can be understood as informative advertisements that are exclusive, such as congratulatory advertisements from one party to another. The difference is that if congratulations originate from outside the advertised object, the death advertisement comes from the advertiser himself, except for the condolences. In the Harian Analisa, on adverts of mourning, represented by children, relatives or family members and other late relatives.

\subsection{Anatomy of Grief Ads}

Grief ads are divided into two, namely Grief and Grief. As where the intact structure of an ad text, both the Condolence Ad, has a part that is drawn in its anatomy. Headline is the opening sentence which informs that this type of advertisement is sorrowful Advertisements. The headlines are located at the top with those printed in upper and lower case letters, namely KABAR DUKACITA or TURUT SUPPORTING. Sub Headlines in ads are transitional sentences between headlines and Names). Some headlines do not require a subheadline, because the subheadline only functions as an introduction to the script or headline explanation. "Has passed away peacefully, son/husband/father/father-inlaw/grandfather/brother/sister-in-law/our belikik" if the News of Grief. If you are sorry, use the word "For the death"

Names are the basic identities of the advertised objects, usually in capital letters and bold. Put in the middle of the advertising structure, below or next to the photo, and generally followed by the identification of other signs, namely the name and age in Chinese letters and 
languages, if Grief News. If the adverts are also sad, indicate the identification, position or family of someone left behind.

Bodycopy is the main content in the grief ad text that describes the event of someone's death and the death ritual that accompanies it. Inside is an identification of signs, namely the time of death, the funeral home and the execution of the ceremony of death, if the News is Grief. If the adverts are also mourned, it reads "Hopefully his spirit will be accepted by the Almighty God and the families left behind are given steadfastness.

Surname is an important element in grief advertising that explains the identity of grieving parties. Under the writings of OUR CONCERNING, in the form of full names of each close family, namely parents, in-laws, sons, daughters, daughter-in-law, son-in-law, male grandchildren, grandchildren outside women, Adik biological male, female siblings, husband of siblings, brother-in-law, wife of sister-in-law, sister-in-law of a sister, husband of sister-in-law, nephew of men, male offspring, nephew outside of women. The series is if in the form of Grief News advertisements. If the advertisement is also sad, only the sender's name is written.

Photos are one element that is always included in sorrow advertisements, especially news advertising. Generally in the form of a photograph or photo half body free. The photo is usually used in a series of ritual ceremonies and is placed on the ash table (Hio Lo). Frames are edge borders/gars that frame an advertisement of mourning. The shape of the frame varies, depending on the creativity of the advertising designer in laying out the grief advertisement in accordance with the standard of the newspaper that contains it. The simplest standard Garus is a thick, square black line. The most complete structure is usually found in sorrow advertisements, while in advertisements condolence, the elements described above are not all displayed

\subsection{Chinese Ethnic Identity in Condolence Ads Harian Analisa Newspaper in Medan.}

Barth (1967: 14), ethnic groups can be identified as long as they show differences with other groups. This difference certainly does not only cover objective and subjective aspects, but it will be better if it integrates with the aspects of socio-cultural dynamics which will certainly affect both elements.

Starting from what was revealed by Barth, it was easy to determine the ethnic Chinese identity among the diversity of ethnic groups in Medan, because it was so different from the physical, religious and behavioral aspects. This is based on the background of the Chinese ethnic itself which is considered difficult to eliminate its identity, cultural elements and teachings of its ancestors. Every ethnic Chinese descendant is required to follow the teachings of his ancestors, even though they come from rich, or poor families.

The Chinese ethnic community is a community that is diligent in carrying out its traditions and cultural activities, one of which is to carry out religious teachings, even though they are outside the area. If we look at the characteristics of ethnic groups in Medan, the ethnic characteristics that are most easily determined are the characteristics of the ethnic Chinese community.

The life and culture of the ethnic Chinese community in Medan is influenced by a belief system originating from Buddhism, Taoism and Confucianism. In addition to the teachings of Buddhism, ethnic Chinese still pay homage to the saints and are considered as gods or goddesses, but Confucianism is the most widely practiced and very strong teaching for the ethnic Chinese community in their country or outside the region. 
These three religious teachings have been maintained by the Chinese community today. This is influenced by past factors, where the belief system has many functions to organize social and cultural life in Chinese society. The group of ethnic Chinese parents directs and emphasizes the teachings of the religion (Buddhist Tri Dharma) to children, which makes the teachings inherent to ethnic Chinese communities to this day.

Confucius, taught that an ideal is called "a respectable person" which means a person who has an honest attitude, and a high morality in all things and obeys the rituals that are right in his behavior. An honorable person in the Chinese sense, where being polite is enough to get the title above. Manners as taught by Confucians are based on three principles, namely respect for the glory of mankind, reasonableness (what is not fair, for someone is also not natural for others) and reliability (willingness to be recipients of behavior and actions).

\subsection{Repay to someone who has helped.}

Other elements that are always added to these three principles are "obligation" or "devotion" which is one's obligation to parents, employers, customers, and the State. This can be seen in the adverts of mourning in the Analytical Newspaper, how the teachings were carried out with a sense of respect for returning the favor to the person who had helped.

Ethnic Chinese in Medan, say thank you or return favor to people who have died in various ways. How to repay the favor, one of which is to send a statement of condolence by preaching it in the Harian Analisa . You could say, that during his lifetime, those who died were well known among them. Good means to be like helping others or indirectly helping other families, so people who have helped, return the favor by expressing condolences.

The act of respecting older people who are meritorious is not only a genealogical parent, but an outsider who is instrumental in their lives. This must be part of the habit if the individual is dedicated to his parents. The learning process always starts from small things and in the daily scope first, by respecting their parents first. Helping to give news by advertising people who make merit in newspapers is also a form of serving parents.

Chinese traditions do require that their children always respect their parents, whether the parent in question is still alive, or has passed away. Respect for parents is called Hao (Hshiao) which for them must be accompanied by respect for older people as a statement of love. This respectful attitude takes place every day for those who are still alive and after death in a different way.

\subsection{Maintain Closer Kinship in the Family .}

Death advertisements can be a place for reunions for all family members, meaning that members who migrate outside the region or even abroad will support the advertising costs in the newspaper, even though they arrive late or do not have time to return home together with all family members. So, it can take days for the ad to be in the Harian Analisa, because the costs are borne by other families in turn.

Communication with good friends, family members, and people who have strong emotional ties, including intimate interactions that build close kinship for the ethnic Chinese. The strength of the relationship determines the climate of interaction that occurs in condolence advertisements that are managed jointly.

In grief advertisements, the teachings are contained so that relationships between families within one ancestor are maintained in informal communication systems. They keep talking and communicating actively outside as the head of the family and get closer to the 
nephews or grandchildren. This intimate interaction, for example about moral teachings about devotion is the most important value in the lives of Chinese people.

All Chinese people must worship the (older) parents who are still alive and to the deceased ancestors. The Chinese believe that if they are not filial, fortune will not come. Parents used to always teach their children to serve older people and respect their ancestors. This devotional value is the most important in Chinese Ethnic communities. Because they believe that the glory of a child can be seen from his devotion to living parents and deceased ancestors by means of worship. If they are not filial, fortune does not come (Suharyanto, 2017).

\subsection{Social Bonding and Togetherness}

Adverts of death can be a place for reunions for all friends and followers for those who die outside of the nuclear family. This means that members who migrate outside the region or even abroad will support advertising costs in the newspaper, even though they do not have time to gather together with other friends. Therefore, it is only natural that grief ads can last for days in the Harian Analisa , because costs are borne by other families alternately.

This could happen because the person who died, during his life, always gathered and had good relations with his group intensely. Heroes outside the nuclear family are awakened with them alternately to express condolences in the Harian Analisa to their comrades who have just died. Not only in one group, but other groups don't want to lose to do the same.

\subsection{Cultural Defense}

The meaning of the tradition of proclaiming death in the mass media is respect for friends, relatives and parents who have contributed to them. It's like a kind of symbolization of the respect of ancestors and gods. Deities in Chinese culture are human beings who are human beings, considered to be living and acting like humans.

In the past, the preaching of someone's death was done by attaching paper to the pillars and walls of the house. Before the notice paper is affixed, they do their homage in a place that will be affixed, So they respectfully do all this and they still do it up to now. Although the progress of the times has changed all aspects of life, they still do this respect. They continued to pay their respects to the Harian Analisa office, before making a notice to order advertisements of mourning in preaching the deaths of family, friends and friends.

\subsection{Respect the Ancestors}

Ancestral respect for Chinese culture is a habit carried out by living family members to try to meet the needs of deceased family members and make them happy in the hereafter. The practice is an effort to continue to show devotion to those who have died, and also strengthen unity in the family and those who are in line. Showing devotion to ancestors is an ideology deeply rooted in Chinese society. The rationale is that child piety is emphasized by the teachings of Confucianism.

Childhood piety is a concept to always love parents as a child. It is believed that even though loved ones have died, the relationships that have occurred so far are still ongoing, and people who have died have greater spiritual power than when they were still alive. The definition is that the ancestors are considered to be gods who have the ability to interact and influence the lives of living family members.

Death is part of every person and creature of God's creation, which is impossible to avoid. Once taken away, regardless of race, economy, age, position, and religion. Humans are 
set to die just once, although we often hear people say there are people who die and live again, usually that is called suspended animation. Human reactions to death vary, depending on who dies. If the dead are close relatives, known or loved, then there is a very deep sense of loss and sadness.

Chinese traditions strongly demand that their children always respect their parents. This tradition is actually reasonable if the intended parent is still alive. What becomes unnatural is when the person is dead, he must be respected and considered as a secretary still alive. Respect for parents, for them must be accompanied by respect for older people as a statement of love. This respectful attitude takes place every day for those who are still alive and after death in a different way.

Preaching to others is very important in this regard which is considered as one of the worship of ancestral spirits. They assume that the human spirit lives on, with adoration, it is hoped that the ancestral spirits will protect their offspring from calamity. The worship of ancestral spirits is merely a warning to the ancestors, namely those who have given life to the present generation. So in other words, maintaining the "ash table" is only to commemorate a deceased parent.

\section{Conclusion}

Mass Media and the Relation of Death Commodities to Chinese Ethnicity in Condolence Advertisements in Harian Analisa Newspapers in Medan are two things that are closely related to respect for ancestors as well as the economy. These two activities, accommodated by a Harian Analisa that presents economic and ethnic Chinese news as a driver of the economy in Medan and the owners also come from ethnic Chinese as well.

Identification of Condolence Advertisements in the Harian Analisa Newspaper in Medan, is a daily newspaper that is used as a medium to proclaim death to family and friends, as a tribute to others. There are two types of death advertisements, namely Grief News and Grief. Anatomy of Grief Ads: Headline; Sub Headline; Name; Bodycopy; Family name; Photos and Frames. Chinese Ethnic Identity, seen from the presence of Condolence Advertisements in Harian Analisa Newspaper as one of the teachings that the brand is still doing to Repay Budi to People Who Ever Helped; Maintain Closer Kinship in the family; Social Bonding and Togetherness, Cultural Defense and Respect for Ancestors.

\section{References}

Agus, Bustanuddin 2006, Agama Dalam Kehidupan Manusia; Pengantar Antropologi Agama, Jakarta: Raja Grafindo Persada.

Arifin, M.T. 1998. Pengakuan Persepsi Terhadap WNI Etnis Tionghoa. dalam Alfian Hamzah(ed.), Kapok Jadi Nonpri: Warga Tionghoa Mencari Keadilan. Bandung: Penerbit Zaman Wacana Mulia, 64-75.

Bachrun, R dan Hartanto, B. 2000. Krisis Identitas Diri Pada Kelompok Minoritas Tionghoa. Dalam Wibowo, I (editor). Harga Yang Harus Dibayar. Sketsa Pergulatan Etnis Tionghoa di Indonesia. Jakarta: Gramedia Pustaka Utama dan Pusat Studi Tionghoa.

Barth, Frederick. 1988. Kelompok Etnis dan Batasannya (terj). Jakarta: UI Press.

Chang, Queeny. 2005. Memories of A Nonya: Kisah Hidup dan Cinta Seorang Wanita Tionghoa Terkaya di Medan. Jakarta; MM Corp. 
Chusman, Jennifer \& Wang Gungwu. 1991. Perubahan Identitas Orang China di Asia Tenggara. Jakarta: Grafiti

Devi, Aulia Vista. 2010. Analisis Wacana Ucapan Terima Kasih dalam Harian Kompas. Skripsi. Universitas Muhamadiyah Surakarta.

Effendy, Onong Uchjana. 1993. Dinamika Komunikasi. Bandung: PT. Remaja Rosdakarya. Hadiluwih, Subanindyo. 1994. Studi Tentang Masalah Tionghoa di Indonesia: Studi Kasus di Medan. Medan: Dian-Doddy.

Ham, Ong Hok. 2005. Riwayat Tionghoa Peranakan di Jawa, Jakarta: Komunitas Bambu. . 2008. Anti Tionghoa, Kapitalisme Tionghoa dan Anti Tionghoa. Jakarta: Komunitas Bambu.

http://id.wikipedia.org/wiki/Kota_Medan

Haviland, William A, Antropologi jilid I dan II Alih bahasa RG Soekardjo, Jakarta : PT. Gramedia, 1970

Ihromi, T.O. 1990. Pokok-pokok Antropologi Budaya. Jakarta: Yayasan Obor Indonesia. Jenks, Christ. 2008. Kebudayaan. Medan: Bina Media Perintis.

Koentjaraningrat, 1985. Beberapa Pokok Antropologi Sosial. Jakarta: Dian Rakyat. 1987. Sejarah Teori Antropologi I Jakarta Universitas Indonesia 2004. Kebudayaan Mentalitas dan Pembangunan. Jakarta Gramedia Pustaka Utama

Lan, T, J. 2000. Susahnya Jadi Orang Tionghoa. Ke-Tionghoa-an Sebagai Konstruksi Sosial. Dalam Wibowo, I (editor). Harga Yang Harus Dibayar. Sketsa Pergulatan Etnis Tionghoa di Indonesia. Jakarta: Gramedia Pustaka Utama dan Pusat Studi Tionghoa.

Mastoyo. 2007. Pengantar Metode Penelitian Bahasa. Yogyakarta:Carasvatibooks.

Moleong, Lexy. 2006. Metodologi Penelitian Kualitatif ed. Revisi. Bandung: PT Remaja Rosdakarya

M, Hidajat Z. 1984. Masyarakat dan Kebudayaan Tionghoa di Indonesia. Bandung: Tarsito. Moleong, Lexy, 2006, Metodologi Penelitian Kualitatif cet 22, Bandung, Remaja Rosda Karya.

Mulyana, Dedy. 2000, Ilmu Komunikasi, Pengantar, Bandung: Remaja. Rosadakarya. Nugraha, Adi. Membaca Kepribadian Orang-orang China. Yogyakarta: Garasi, 2008.

Pelly, Usman. Urbanisasi dan Adaptasi, Peranan Misi Budaya Minangkabau dan Mandailing. Jakarta: LP3ES, 1998, hal. 91.

Rakhmat, Jalaludin, 1988, Psikologi Komunikasi, CV. Remaja Karya, Bandung.

Suharso, Drs Dkk. 2009. Kamus Besar Bahasa Indonesia Edisi Lux. Semarang:CV Widya Karya.

Spradley, James P. 1997. Metode Etnografi. Yogya: Tiara Wacana.

Suparlan, Parsudi, ed. Manusia, Kebudayaan dan Lingkunganya. Jakarta: Rajawali. 1984

Suranto, AW, 2011, Komunikasi Interpersonal, Yogyakarta: Graha Ilmu.

Suryadinata, Leo. 1994. Politik Tionghoa Peranakan di Indonesia. Jakarta: Sinar Harapan. 